\title{
Effect of ambient temperature and sodium bicarbonate supplementation on water and electrolyte balances in dry and lactating Holstein cows
}

\author{
H. Khelil-Arfa, ${ }^{*} \dagger$ P. Faverdin, ${ }^{*} \dagger$ and A. Boudon ${ }^{*} \dagger^{1}$ \\ *INRA, UMR 1348 PEGASE (Physiologie Environnement et Génétique pour l'Animal et le Système d'Elevage), F-35590 Saint-Gilles, France \\ †Agrocampus Ouest, UMR1348 PEGASE F-35000 Rennes, France
}

\begin{abstract}
The aim of this study was to quantify the effect of the interaction between 2 constant ambient temperatures [thermoneutrality $\left(\mathrm{TN} ; 15^{\circ} \mathrm{C}\right)$ and high temperature $\left.\left(\mathrm{HT} ; 28^{\circ} \mathrm{C}\right)\right]$ and 2 levels of $\mathrm{Na}$ bicarbonate supplementation [calculated to provide diet $\mathrm{Na}$ contents of $0.20 \% \mathrm{DM}(\mathrm{Na}-)$ and $0.50 \% \mathrm{DM}(\mathrm{Na}+)]$ on water partitioning in dairy cows. Treatments were compared on 4 dry and 4 mid-lactation Holstein cows according to 2 Latin squares ( 1 for each physiological stage) over the course of 4 periods of $15 \mathrm{~d}$. Diets consisted of a total mixed ration based on maize silage. Dry cows were restricted to their protein and energy requirements, whereas lactating cows were fed ad libitum. The daily average temperature-humidity index was 59.4 for TN and 73.2 for HT. Lactating and dry cows had higher vaginal temperatures at $\mathrm{HT}$ than at $\mathrm{TN}$, but the increase was more pronounced in lactating cows $(+1.05$ vs. $+0.12^{\circ} \mathrm{C}$ for vaginal temperature, respectively). Dry matter intake (DMI) of lactating cows decreased by 2.3 $\mathrm{kg} / \mathrm{d}$ at HT. Free water intake (FWI) and estimated volume of water lost to evaporation increased at HT in both lactating and dry cows; no interactions were observed between temperature and physiological stage. When expressed as a proportion of DMI, the increase in evaporation that occurred with increasing temperature was completely compensated for by an increase in FWI for both physiological stages. The urinary water excretion increased slightly at HT in lactating cows but not in dry cows, which may be related to the low chloride content of the offered diet. High $\mathrm{Na}$ supplementation increased DMI slightly in lactating cows, but milk yield was not affected. Sodium supplementation did not limit the decrease in DMI observed in lactating cows at HT; this observation is likely due to the high diet electrolyte balance of the offered diets. Sodium supplementation increased FWI in lactating cows and urinary flow in both physiological states. The interaction between
\end{abstract}

Received May 30, 2013.

Accepted December 16, 2013.

${ }^{1}$ Corresponding author: anne.boudon@rennes.inra.fr ambient temperature and $\mathrm{Na}$ supplementation did not affect either water intake or water evaporation. This study demonstrates that the development of predictive models for water intake that include environmental variables could be based on mechanistic models of evaporation.

Key words: water intake, water excretion, high temperature, dairy cow

\section{INTRODUCTION}

Even though dairy herd drinking water represents only 1 to $2 \%$ of the total amount of water needed to produce milk on a national scale (Mekonnen and Hoekstra, 2012), its supply is vital for dairy herds. A loss of $20 \%$ of body water is fatal to cows (NRC, 2001), and an inadequate supply of drinking water will rapidly cause a marked reduction in intake and milk production (Steiger Burgos et al., 2001). At high ambient temperatures, a lack of drinking water will also impair the ability of cows to adapt to heat (Silanikove, 2000). In intensive systems, drinking water can be supplied by the public water service, which can be very expensive. In this context, it is important to rely on accurate modeling of dairy herd drinking water requirements to ensure that the water supply is not limiting for the herd (especially during warm and dry weather periods) or to build tools that can be used to detect water leaks on farm water distribution networks.

Numerous empirical equations have been developed to predict water intake in dairy cows (Murphy et al., 1983; Holter and Urban, 1992; Khelil-Arfa et al., 2012); however, most of these equations were established in the context of thermoneutrality and, thus, rarely incorporated meteorological measurements as predictors. The increase in water loss by evaporation is the first heat adaptation mechanism of homeothermic animals. For producing dairy cows, homeostatic mechanisms aim to maintain homeothermy by increasing heat dissipation via evaporation at ambient temperatures of $14^{\circ} \mathrm{C}$ or higher (Maia et al., 2005a,b). When meteorological measurements were included in the abovementioned equations, they were generally introduced in the 
form of multiple regressions from data obtained from a single experimental farm. The risk of this method consists of the possible confounding of meteorological variables, the physiological stage, production level, or diets of the cows throughout the year. An alternative more mechanistic way of including meteorological or environmental variables in predictive equations would be to use published models of the effects of ambient temperature on water evaporation in cows obtained from instantaneous measurements taken in numerous environmental conditions with animals on various feeds and at different physiological stages (Turnpenny et al., 2000; CIGR, 2002; Maia et al., 2005a). This could allow the inclusion of environmental variables in such a way that the predictive equations could be used across geographic contexts. However, this method also assumes that we are cognizant of the effects of an increase in water evaporation on the drinking water requirements of a dairy cow and, more generally, how this increase will affect water partitioning in cows.

Dairy cows lose water through evaporation, urine, feces, and milk production, and the pool of the cow's body water is maintained through water intake from drinking (free water intake, FWI), feed, and metabolic oxidation in body tissues. When ambient temperatures increase above $14^{\circ} \mathrm{C}$, the increase in evaporated water is generally accompanied by a clear increase in FWI (McDowell et al., 1969; Seif et al., 1973; Kurihara et al., 1984). However, it has also been observed on dry cows that urinary water excretion can increase during heat exposure (El-Nouty et al., 1980; Kurihara et al., 1984). Given that the observed increases in urinary water flow at high ambient temperatures in dry cows was reported on the very first days of heat exposure (El-Nouty et al., 1980; Kurihara et al., 1984) and given that these very first days are characterized by a high and transient increase in the amount of water in the body (Richards, 1985), it is unclear whether the increase in urinary water excretion with increasing temperature is specific to dry cows or to the first days of heat exposure.

High ambient temperatures also strongly modify the electrolyte and acid-base balance of dairy cows for 3 reasons: first, because potassium is the main cation encountered in bovine sweat (Jenkinson and Mabon, 1973); second, because $\mathrm{Na}$ is excreted with bicarbonates to compensate for the respiratory alkalosis that can occur during heat stress in cows (West, 2003); and third, because the diurnal excretion of bicarbonates can induce metabolic acidosis during the cooler periods of the day (Schneider et al., 1988). A better adaptation of dairy cows to high temperatures can be achieved by increasing $\mathrm{Na}$ and $\mathrm{K}$ bicarbonate supplementation in the diet (West, 2003). However, the effects of this practice on water needs and water partitioning in dairy cows that are exposed to heat stress have not been assessed. Given that $\mathrm{Na}$ is the most important electrolyte of the extracellular pool and a major ion involved in the regulation of the renal reabsorption of water and urinary volume (Meyer et al., 2004), Na supplementation may strongly increase urinary water excretion and water requirements of cows.

The overall objective of the present study was to determine the effects of high ambient temperatures on water and electrolyte partitioning (in relation to acid-base regulation) in dry or lactating cows fed diets supplemented with 1 of 2 levels of Na bicarbonates during a second week of heat exposure. The first objective of the study was to determine if the increase in water evaporation at high temperatures was compensated for by an increase in FWI when body water pools were stabilized; if so, thermic models of ruminants could be used to predict the water requirements of cows associated with certain environmental conditions at various geographic sites. The second objective of the study was to determine whether the effect of $\mathrm{Na}$ supplementation on urinary water excretion and drinking water was similar at high ambient temperatures and under thermoneutral conditions.

\section{MATERIALS AND METHODS}

\section{Animals and Experimental Design}

The 4 treatments consisted of a factorial arrangement of 2 ambient temperatures [thermoneutrality $\left(\mathbf{T N} ; 15^{\circ} \mathrm{C}\right)$ or high temperature $\left.\left(\mathbf{H T} ; 28^{\circ} \mathrm{C}\right)\right]$ and 2 levels of feed $\mathrm{Na}$ [high $(\mathbf{N a}+)$ or low $(\mathbf{N a}-)$ levels of supplementation]. These treatments were compared in 4 lactating multiparous Holstein cows $[98.5 \pm 3.32$ DIM; $42.1 \pm 5.1 \mathrm{~kg} / \mathrm{d}$ milk yield (MY); $653 \pm 35.2 \mathrm{~kg}$ of BW] and 4 dry Holstein cows (702 $\pm 95 \mathrm{~kg}$ of BW) over the course of 4 periods of $12 \mathrm{~d}$ according to two $4 \times 4$ Latin square designs (1 for each physiological stage). None of the cows was pregnant at the beginning the experiment. The ambient temperatures were concomitantly produced with 2 climatic chambers housing 2 lactating and 2 dry cows and 2 cows on $\mathrm{Na}+$ and 2 cows on $\mathrm{Na}-$. The succession of treatments was organized to avoid 2 consecutive HT periods for the same cow. In each chamber, the ambient temperature was maintained constant throughout the day with a thermostatic convective heating system. Hygrometry was not regulated. The dry bulb temperature, relative humidity, and air speed were controlled in both chambers. In the chambers, cows were housed in individual tie-stalls $(1.4 \times 2.0 \mathrm{~m})$ with individual troughs and individual water bowls providing free access to water. The four 12-d periods comprised $8 \mathrm{~d}$ of adaptation to treatments 
Table 1. Composition of the offered TMR (DM basis) for the Naand $\mathrm{Na}+$ treatments $^{1}$

\begin{tabular}{|c|c|c|}
\hline \multirow[b]{2}{*}{ Item } & \multicolumn{2}{|c|}{ Treatment } \\
\hline & $\mathrm{Na}-$ & $\mathrm{Na}+$ \\
\hline \multicolumn{3}{|l|}{ Ingredient (\%) } \\
\hline Corn silage & 74.5 & 73.0 \\
\hline Dehydrated alfalfa & 10.0 & 10.0 \\
\hline Soybean meal, $48 \%$ & 13.8 & 13.8 \\
\hline Mineral-vitamin premix ${ }^{2}$ & 1.2 & 1.2 \\
\hline $\mathrm{NaHCO}_{3}^{-}$ & 0.5 & 1.9 \\
\hline TMR DM (\%) & 40.4 & 40.4 \\
\hline \multicolumn{3}{|c|}{ Chemical composition (\% DM) } \\
\hline $\mathrm{OM}$ & 93.4 & 92.0 \\
\hline $\mathrm{CP}$ & 14.7 & 14.0 \\
\hline $\mathrm{NDF}$ & 34.1 & 35.0 \\
\hline $\mathrm{ADF}$ & 18.6 & 19.1 \\
\hline ADL & 2.2 & 2.3 \\
\hline $\mathrm{Ca}$ & 0.72 & 0.72 \\
\hline $\mathrm{P}$ & 0.31 & 0.31 \\
\hline $\mathrm{Na}$ & 0.206 & 0.489 \\
\hline $\mathrm{Cl}$ & 0.21 & 0.21 \\
\hline K & 1.22 & 1.27 \\
\hline \multicolumn{3}{|l|}{ Nutritional value } \\
\hline $\mathrm{PDIE}^{3}(\%$ of DM) & 9.2 & 9.1 \\
\hline $\operatorname{PDIN}^{4}(\%$ of DM) & 8.9 & 8.9 \\
\hline $\mathrm{NE}_{\mathrm{L}}(\mathrm{MJ} / \mathrm{kg}$ of $\mathrm{DM})$ & 6.32 & 6.25 \\
\hline $\mathrm{EB}^{5}(\mathrm{mEq} / \mathrm{kg}$ of $\mathrm{DM})$ & 343 & 479 \\
\hline
\end{tabular}

${ }^{1} \mathrm{Na}-=$ diet formulated with a low level of Na supplementation; $\mathrm{Na}+$ $=$ diet formulated with a high level of $\mathrm{Na}$ supplementation.

${ }^{2}$ Contained $27 \%$ calcium, $5.5 \%$ phosphorus, $4 \%$ magnesium, $600 \mathrm{kIU}$ of vitamin $\mathrm{A} / \mathrm{kg}, 80 \mathrm{kIU}$ of vitamin $\mathrm{D}_{3} / \mathrm{kg}, 1.5 \mathrm{kIU}$ of vitamin $\mathrm{E} / \mathrm{kg}$, $4,000 \mathrm{mg}$ of $\mathrm{Zn} / \mathrm{kg}, 4,000 \mathrm{mg}$ of $\mathrm{Mn} / \mathrm{kg}, 1,000 \mathrm{mg}$ of $\mathrm{Cu} / \mathrm{kg}$ (sulfate and chelate), $80 \mathrm{mg}$ of I/ kg, $20 \mathrm{mg}$ of $\mathrm{Co} / \mathrm{kg}$, and $20 \mathrm{mg}$ of Se/kg.

${ }^{3}$ Protein digestible in the small intestine supplied by microbial protein from rumen-fermented OM (INRA, 2007).

${ }^{4}$ Protein digestible in the small intestine supplied by microbial protein from rumen-degradable protein (INRA, 2007)

${ }^{5}$ Diet electrolyte balance $([\mathrm{Na}]+[\mathrm{K}]-[\mathrm{Cl}]$, in $\mathrm{mEq} / \mathrm{kg}$ of dietary $\mathrm{DM})$.

and $4 \mathrm{~d}$ of measurements. Two days at $15^{\circ} \mathrm{C}$ were included between each period. The ambient temperature was increased by $2^{\circ} \mathrm{C} / \mathrm{h}$ during the first day of the $\mathrm{HT}$ periods starting at $0900 \mathrm{~h}$. The trial included a 2 -wk preexperimental adaptation period at $15^{\circ} \mathrm{C}$ to monitor voluntary DMI and a 1 wk postexperimental period. The experiment took place at the Institut national de la recherche agronomique (INRA) experimental farm of Méjusseaume (Brittany, France; longitude $-1.71^{\circ}$, latitude +48.11) from December 26, 2009, to February 19, 2010. Procedures relating to the care and use of animals for the experiment were approved by an animal care committee of the French Ministry of Agriculture in accordance with French regulations (Decree law 2001464, May 29, 2001).

\section{Diets and Animal Feeding}

Two TMR based on maize silage and differing in the level of $\mathrm{Na}$ bicarbonate $\left(\mathrm{NaHCO}_{3}{ }^{-}\right)$supplementation were formulated (Table 1). Both diets were formulated to meet the energy and protein requirements of the lactating cows according to INRA (2007), with $14 \mathrm{~g}$ of digestible protein in the small intestine/MJ of $\mathrm{NE}_{\mathrm{L}}$ (the equivalent of MP in the INRA feeding system), which was equivalent to $22.6 \mathrm{~g}$ of $\mathrm{CP} / \mathrm{MJ}$ of $\mathrm{NE}_{\mathrm{L}}$ in this experiment. The quantities of mineral premix included in the diet were also calculated to meet the $\mathrm{Ca}$ and $\mathrm{P}$ requirements of the lactating cows according to INRA (2007) and the $\mathrm{Mg}$, En, Mn, Cu, I, Co, Se, and vitamin A, D, and E requirements according to Meschy (2010). The quantity of TMR offered to dry cows was limited to $14 \mathrm{~kg}$ of DM/d to avoid excessive weight gain. This amount allowed an energy intake equivalent to 2 times the maintenance requirement of dry cows. The $\mathrm{Na}-$ diet $(2.0 \mathrm{~g}$ of $\mathrm{Na} / \mathrm{kg}$ of $\mathrm{DM})$ was formulated to meet the Na requirement of a $600-\mathrm{kg}$ lactating cow producing $40 \mathrm{~kg}$ of milk/d and exposed to thermoneutral conditions (Meschy, 2010). The $\mathrm{Na}^{+}$diet was formulated to provide $5.0 \mathrm{~g}$ of $\mathrm{Na} / \mathrm{kg}$ of $\mathrm{DM}$ in the diet, a quantity determined by Schneider et al. (1986) as an optimal dose to improve heat adaptation. The Na content of the diets was adjusted with $\mathrm{NaHCO}_{3}{ }^{-}$and the $\mathrm{NaHCO}_{3}{ }^{-}$ replaced a portion of maize silage in the $\mathrm{Na}^{+}$diet. To control mineral supply, no straw or mineral blocks were provided. Two equal-sized meals per day were provided at 0830 and $1730 \mathrm{~h}$ and orts were recorded daily before the a.m. and p.m. feedings. Lactating cows were fed ad libitum and offered quantities were calculated to allow $10 \%$ refusals. Lactating cows were milked twice daily at 0630 and $1700 \mathrm{~h}$ in the climatic chambers.

\section{Measurements of Environmental Conditions, Body Temperatures, and Respiratory Rates of Cows}

The air temperature, relative humidity, and air velocity were recorded continuously at 15-min intervals in each climatic chamber using temperature and relative humidity probes (HMP 45C; Campbell Scientific Inc., Courtaboeuf, France) and a hot wire anemometer (8450-20M-V-STD-NC-F; TSI Inc., Shoreview, MN) placed at a height of $1.6 \mathrm{~m}$ in a central position between the cows and connected to a data acquisition system (CR 1000; Campbell Scientific Inc.).

Vaginal temperatures were continuously measured at 15-min intervals throughout the entire experiment with vaginal indwelling telemetric temperature probes (Vel'Phone; Medria, Châteaugiron, France). Probes were inserted into the cow during the adaptation period. Respiratory rates, heart rates, and skin temperatures were measured at 0800,1500 , and $2100 \mathrm{~h}$ on d 8 . Respiration rates were determined by counting flank movements for $60 \mathrm{~s}$ by 2 observers until the difference between the 2 observers was lower than $15 \%$ of the average. 


\section{Intake, Milk Production, and Water and Electrolyte Balances of Cows}

Intake. Quantities of feed offered and refused were weighed at each feed distribution. Before each distribution, refusals of each cow were removed and weighed. After weighing the amount of feed to be distributed, rations were stored at $4^{\circ} \mathrm{C}$ before being moved into the climatic chambers about $1 \mathrm{~h}$ before distribution. Each day of the measurement period, before the a.m. and p.m. feeding, 2 representative samples (500 g, fresh) of each offered diet were sampled and oven dried $\left(80^{\circ} \mathrm{C}\right.$ for $48 \mathrm{~h}$ ) before being pooled by period. Refusals $(1 \mathrm{~kg}$, fresh) were also sampled from each cow before the a.m. and p.m. feeding and oven dried for DM determination before being pooled by cow and period. Offered and refused feed samples were further analyzed for OM, fiber (NDF, ADF, and ADL), CP, and $\mathrm{Na}, \mathrm{K}$, and $\mathrm{Cl}$ contents. The daily volumes of water taken in by cows were recorded daily at $0830 \mathrm{~h}$, using water meters (model P38; Schlumberger Ltd., Paris, France; nominal flow rate: $1.5 \mathrm{~m}^{3} / \mathrm{h}$; maximum allowable pressure: $1.2 \mathrm{MPa}$ attached to each drinking bowl. Water was sampled at the end of each period for $\mathrm{Na}, \mathrm{K}$, and $\mathrm{Cl}$ contents.

Milk. Milk production was measured individually at each milking and $100 \mathrm{~mL}$ of milk per cow per milking was sampled from d 9 to 11. Daily samples were pooled by cow and period in proportion with the amount of milk produced at each milking; samples were then frozen at $-20^{\circ} \mathrm{C}$ for further analysis (fat, protein, $\mathrm{DM}, \mathrm{Na}$, $\mathrm{K}$, and $\mathrm{Cl}$ contents).

Feces. To determine the fecal DM excreted over 24 $\mathrm{h}$, gross fecal output was weighed and sampled at 0900 $\mathrm{h}$ from d 11 to 13 . Two representative samples (500 g of fresh feces for each sample) were oven dried $\left(80^{\circ} \mathrm{C}\right.$ for $72 \mathrm{~h}$ ) to determine DM content and the daily amount of fecal DM excreted. To determine the daily amount of fecal water excreted, 5 additional fecal samples $(300 \mathrm{~g}$, fresh) were collected at 2-h intervals from 1000 to 1800 $\mathrm{h}$ directly from the cow on each collection day and oven dried $\left(80^{\circ} \mathrm{C}\right.$ for $\left.72 \mathrm{~h}\right)$. The aim of this procedure was to obtain fecal samples that were not affected by losses of water and nitrogen from volatilization due to high temperatures. The amount of fecal water excreted was calculated from the daily amount of fecal DM excreted, and the fecal DM content was determined by sequential sampling. The fecal samples used for the unbiased estimates of DM content were bulked per cow and per period, ground though a $0.8-\mathrm{mm}$ screen, and stored at $4^{\circ} \mathrm{C}$ for further determination of $\mathrm{OM}, \mathrm{NDF}, \mathrm{Na}, \mathrm{K}$, and $\mathrm{Cl}$ contents.

Urine. Daily volumes of excreted urine were measured on d 11 to 13 by equipping cows with harnesses designed for urine collection that were connected by a Tygon tube to a 25 -L container closed with a rubber plug. Sunflower oil $(1 \mathrm{~L})$ and $15 \mathrm{~g}$ of thymol were added to the container to prevent the evaporation and deterioration of urine, respectively. The urine was weighed and the containers were emptied twice per day before feedings. Subsamples $(2 \mathrm{~mL})$ were collected and frozen at $-20^{\circ} \mathrm{C}$ for further analyses of $\mathrm{Na}, \mathrm{K}$, and $\mathrm{Cl}$ contents.

Water Retention. To assess body water retention, cows were weighed, throughout the entire experiment, every Friday morning (d 5 and 12 of each period) between 0730 and $0800 \mathrm{~h}$, after the morning milking and before the first meal.

\section{Blood Gases}

At the beginning of the trial, cows were equipped with a catheter in the left jugular vein and the catheters were filled with a sterile solution of $9 \% \mathrm{NaCl}$ and $200 \mathrm{IU}$ of heparin $/ \mathrm{mL}$. On d 8 of each period, jugular blood was sampled at 0900, 1530, and $2100 \mathrm{~h}$ using 2-mL blood gas syringes (S-Monovette; Sarstedt AG \& Co., Nümbrecht, Germany). Blood pH, partial pressure of $\mathrm{CO}_{2}\left(\mathbf{p C O}_{2}\right)$, partial pressure of $\mathrm{O}_{2}$, and $\mathrm{HCO}_{3}{ }^{-}$concentrations were analyzed immediately by potentiometry (ABL 500 instrument; Radiometer, Copenhagen, Denmark). Blood gases were measured in the $10 \mathrm{~min}$ following sampling time.

\section{Chemical Analyses}

Samples of offered and refused diets and feces were ground with a 3-blade knife mill through a $0.8-\mathrm{mm}$ screen. Content of $\mathrm{OM}$ was determined by calcination at $550^{\circ} \mathrm{C}$ for $5 \mathrm{~h}$ in a muffle furnace. Nitrogen concentration was determined with the Dumas method [NF V 18-120 (AFNOR, 1997); AFNOR, La Plaine SaintDenis, France] on a Leco apparatus (Leco Corp., St. Joseph, MI). Contents of NDF, ADF, and ADL were determined with a Fibersac extraction unit (Ankom Technology Corp., Fairport, NY) according to the Association Française de Normalisation (AFNOR) methods [NF EN ISO 16472 (AFNOR, 2006) and NF EN ISO 13906 (AFNOR, 2008)]. Minerals (Na and K) were measured by atomic absorption spectrophotometry (Spectra-AA20; Varian SA, Les Ulis, France) of mineralized samples (NF EN ISO 6869; AFNOR, 2002). Content of $\mathrm{Cl}$ in urine and milk was measured using a kit for chloride determination (kit 80005; Biolabo S.A., Maizy, France) and content of $\mathrm{Cl}$ in feed and feces was determined by titrimetry according to the Volhard method (NF EN ISO 6495; AFNOR, 2011). Milk DM content was determined in an oven at $100^{\circ} \mathrm{C}$ for $7 \mathrm{~h}$ for 
milk with sand (NF V 04-367; AFNOR, 1985). Milk fat and protein concentrations were determined by nearinfrared spectrophotometry (MilkoScan; Foss Electric A/S, Hillerød, Denmark).

\section{Calculations}

The temperature-humidity index (THI) was calculated using the formula described by Mader et al. (2006). Water losses due to evaporation were calculated as the difference between input (drinking and feed) and output (milk, feces, and urinary water) water, corrected by the body water retention during the measurement period and the gain of metabolic water. Daily water retention was estimated as the difference between the weight of the cows at $\mathrm{d} 5$ and 12 divided by $7 \mathrm{~d}$. Metabolic water was estimated using the equivalent of 0.002 $\mathrm{g} / \mathrm{d}$ of water produced per $1 \mathrm{MJ} / \mathrm{d}$ of heat production (M. Vermorel, INRA Clermont-Ferrand-Theix, France, personal communication). Heat production was calculated from INRA (2007) as the difference between ME intake in megajoules per day and the sum of the amount of energy lost in milk $(\mathrm{MJ} / \mathrm{d})$ and the $\mathrm{NE}_{\mathrm{L}}$ balance (difference between the feed $\mathrm{NE}_{\mathrm{L}}$ supply and the cow $\mathrm{NE}_{\mathrm{L}}$ requirements; $\mathrm{MJ} / \mathrm{d}$ ).

\section{Statistical Analyses}

Data related to measurements of animals were analyzed with the PROC MIXED function of SAS (SAS OnlineDoc, version 8; SAS Institute Inc., Cary, NC) with the following model:

$$
\begin{gathered}
\mathrm{Y}_{\mathrm{ijkl}}=\mu+\mathrm{P}_{\mathrm{i}}+\text { Temp }_{\mathrm{j}}+\mathrm{Na}_{\mathrm{k}}+\text { Stage }_{\mathrm{l}}+\mathrm{Temp}_{\mathrm{j}} \\
\times \mathrm{Na}_{\mathrm{k}}+\mathrm{P}_{\mathrm{i}} \times \text { Stage }_{\mathrm{l}}+\text { Temp }_{\mathrm{j}} \times \text { Stage }_{\mathrm{l}}+\mathrm{Na}_{\mathrm{k}} \\
\times \text { Stage }_{\mathrm{l}}+\text { Temp }_{\mathrm{j}} \times \mathrm{Na}_{\mathrm{k}} \times \text { Stage }_{\mathrm{l}}+\varepsilon_{\mathrm{ijkl}},
\end{gathered}
$$

where $Y_{\mathrm{ijkl}}$ is the analyzed variable, $\mu$ is the overall mean, $\mathrm{P}_{\mathrm{i}}$ is the effect of period $(1 \mathrm{df}), \mathrm{Temp}_{\mathrm{j}}$ is the effect of ambient temperature (TN vs. HT; $1 \mathrm{df}$ ), $\mathrm{Na}_{\mathrm{k}}$ is the effect of the level of $\mathrm{Na}$ supplementation ( $\mathrm{Na}+$

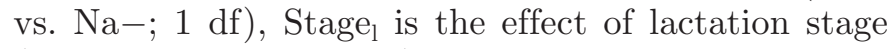
(lactating vs. dry; $1 \mathrm{df}$ ), and $\varepsilon_{\mathrm{ijkl}}$ is the residual error. The effect of cows nested in the lactation stage was used as a random effect. Two sets of 3 orthogonal contrasts were used separately for dry and lactating cows to obtain the $P$-values associated with the $\mathrm{Na}$, temperature and $\mathrm{Na} \times$ temperature effects for each physiological stage.

\section{RESULTS AND DISCUSSION}

\section{Environmental Conditions and Effect of TN and HT Treatments on Feed Intake, Milk Production and Composition, and Thermoregulation and Acid-Base Metabolism Responses}

The mean daily ambient temperature, relative humidity, and unadjusted THI were $15.5^{\circ} \mathrm{C}, 54.3 \%$, and 59.4 , respectively, for $\mathrm{TN}$, and $28.4^{\circ} \mathrm{C}, 28.9 \%$, and 73.2, respectively, for HT. Temperature and relative humidity remained constant throughout the day and throughout the experimental period, with a standard error for hourly ambient temperature throughout the period of 1.44 and $1.01^{\circ} \mathrm{C}$ for $\mathrm{TN}$ and $\mathrm{HT}$, respectively, and a standard error for relative humidity of 8.33 and $4.23 \%$ for $\mathrm{TN}$ and $\mathrm{HT}$, respectively. The air velocity at a height of $1.6 \mathrm{~m}$ was, on average, $0.07( \pm 0.055)$ and $0.41( \pm 0.150) \mathrm{m} / \mathrm{s}$ for TN and HT, respectively, which corresponds to adjusted THI of 66.0 for TN and 78.7 for HT according to Mader et al. (2006), and assuming that cows did not receive solar radiation.

The average temperature achieved for $\mathrm{TN}$ was in the range of thermoneutrality for dairy cows (Berman et al., 1985). This remains true whether thermoneutrality is defined as the range of temperatures within which body temperature is regulated and respiration rate does not increase (Berman et al., 1985) or as the range of temperature within which temperature regulation is achieved by non-evaporative physical processes alone (Silanikove, 2000; Maia et al., 2005a,b). The average daily temperature achieved for HT was above the critical temperature of $25^{\circ} \mathrm{C}$ at which the thermoregulation of cows is impaired (Berman et al., 1985) and the THI was above the THI threshold defining mild heat stress in dairy cows (Armstrong, 1994). When including air velocity in the calculation of adjusted THI (Mader et al., 2006), adjusted THI was higher than 78 , which was considered as the THI threshold defining actual heat stress in dairy cows (Armstrong, 1994). These thresholds may have even been underestimated for modern animal productivity (Berman, 2005).

For lactating cows, DMI decreased by $2.3 \mathrm{~kg} / \mathrm{d}$ between TN and HT [SE of the difference $($ SED) $=0.63$, $P \leq 0.01$; Table 2], whereas for dry cows, DMI was similar to the fed amounts for both HT and TN. Compared with TN, HT decreased MY $(-2.0 \mathrm{~kg} / \mathrm{d} ; \mathrm{SED}=$ $1.69 ; P \leq 0.10)$, milk DM content $(-0.3$ points; SED $=$ $0.32 ; P \leq 0.01)$, fat content $(-1.4 \mathrm{~g} / \mathrm{kg} ; \mathrm{SED}=2.72$; $P \leq 0.05)$, and protein content $(-2.1 \mathrm{~g} / \mathrm{kg} ; \mathrm{SED}=$ $0.72 ; P \leq 0.01)$ of lactating cows. The effects observed on milk composition were in accordance with expected 
Table 2. Effects of ambient temperature and Na supplementation on DMI, milk production and composition, and heat production of lactating and dry cows

\begin{tabular}{|c|c|c|c|c|c|c|c|c|c|}
\hline \multirow[b]{3}{*}{ Item } & \multirow[b]{3}{*}{ Stage $^{1}$} & \multicolumn{4}{|c|}{ Treatment $^{2}$} & \multirow[b]{3}{*}{$\mathrm{SEM}^{3}$} & \multirow{2}{*}{\multicolumn{3}{|c|}{$P$-value ${ }^{4}$}} \\
\hline & & \multicolumn{2}{|c|}{$\mathrm{TN}$} & \multicolumn{2}{|c|}{$\mathrm{HT}$} & & & & \\
\hline & & $\mathrm{Na}-$ & $\mathrm{Na}+$ & $\mathrm{Na}-$ & $\mathrm{Na}+$ & & Temp & $\mathrm{Na}$ & Temp $\times \mathrm{Na}$ \\
\hline \multicolumn{10}{|l|}{ Intake } \\
\hline \multirow[t]{2}{*}{ DMI $(\mathrm{kg} / \mathrm{d})$} & Lact & 20.9 & 21.3 & 18.5 & 19.0 & \multirow[t]{2}{*}{0.47} & $\leq 0.01$ & $\leq 0.05$ & 0.94 \\
\hline & Dry & 13.8 & 13.9 & 13.8 & 13.9 & & 0.99 & 0.61 & 0.99 \\
\hline \multirow{2}{*}{ Offered DM content (\%) } & Lact & 40.4 & 40.7 & 40.4 & 40.9 & \multirow[t]{2}{*}{0.08} & 0.28 & $\leq 0.01$ & $\leq 0.10$ \\
\hline & Dry & 40.0 & 40.4 & 40.0 & 40.4 & & 1.00 & $\leq 0.01$ & 1.00 \\
\hline NDF orts (\%) & Lact & 44.5 & 43.2 & 40.4 & 40.8 & 1.58 & $\leq 0.1$ & 0.75 & 0.56 \\
\hline $\mathrm{CP}$ orts $(\mathrm{g} / \mathrm{kg}$ of $\mathrm{DM})$ & Lact & 115.6 & 115.3 & 134.7 & 131.2 & 4.70 & $\leq 0.01$ & 0.59 & 0.63 \\
\hline \multicolumn{10}{|l|}{ Milk } \\
\hline Yield (kg/d) & Lact & 31.3 & 30.0 & 28.3 & 29.1 & 1.34 & $\leq 0.10$ & 0.77 & 0.27 \\
\hline DM content (\%) & Lact & 12.10 & 12.25 & 11.75 & 11.98 & 0.235 & $\overline{\leq} 0.01$ & $\leq 0.05$ & 0.56 \\
\hline Fat content $(\mathrm{g} / \mathrm{kg})$ & Lact & 38.8 & 40.3 & 37.5 & 38.7 & 1.93 & $\leq 0.05$ & $\leq 0.05$ & 0.73 \\
\hline Protein content $(\mathrm{g} / \mathrm{kg})$ & Lact & 30.0 & 30.0 & 28.0 & 27.8 & 0.51 & $\leq 0.01$ & 0.74 & 0.71 \\
\hline Lactose content $(\mathrm{g} / \mathrm{kg})$ & Lact & 46.50 & 48.72 & 48.35 & 46.55 & 1.275 & 0.88 & 0.85 & 0.11 \\
\hline $\operatorname{IHP}^{5}(\mathrm{MJ} / \mathrm{d})$ & Lact & 64.6 & 63.4 & 57.4 & 59.9 & 3.22 & $\leq 0.05$ & 0.73 & 0.34 \\
\hline \multirow[t]{2}{*}{$\mathrm{BW}(\mathrm{kg})$} & Lact & 632.5 & 633.7 & 622.1 & 623.7 & \multirow[t]{2}{*}{26.51} & $\leq 0.05$ & 0.71 & 0.95 \\
\hline & Dry & 766.7 & 786.0 & 763.2 & 771.7 & & 0.97 & 0.25 & 0.38 \\
\hline \multirow[t]{2}{*}{ Variation of BW in wk $2(\mathrm{~kg})$} & Lact & 4.5 & 7.0 & -12.0 & -9.0 & \multirow[t]{2}{*}{3.72} & $<0.01$ & 0.47 & 0.94 \\
\hline & Dry & 0.2 & 2.7 & -1.0 & 3.7 & & 0.97 & 0.34 & 0.76 \\
\hline \multirow{2}{*}{ Heat production (MJ/d) } & Lact & 126.5 & 125.4 & 118.4 & 121.1 & \multirow[t]{2}{*}{3.08} & $\leq 0.01$ & 0.56 & 0.2 \\
\hline & Dry & 71.4 & 71.5 & 71.2 & 71.7 & & 0.99 & 0.79 & 0.84 \\
\hline
\end{tabular}

results in cows under heat stress, with a decrease in milk protein and fat contents that can also be observed in such experiments (Bernabucci et al., 2010). This led, in this present experiment, to a decrease of the milk DM content at HT.

The responses of cows to $\mathrm{HT}$ and $\mathrm{TN}$ in our experiment illustrated that both lactating and dry cows need to make physiological adjustments to heat and that the thermoregulatory capacities of lactating cows were insufficient at HT. At both physiological stages, daily respiration rate was higher at HT than at TN $(+27.0$ and +17.4 inspirations/min in lactating and dry cows, respectively; SED $=3.59 ; P \leq 0.0001$; Table 3 ). At HT, daily respiration rates were close or higher than 40 inspirations/min, indicating that cows were panting to increase body cooling (Silanikove, 2000). Compared with TN, HT increased vaginal temperatures of cows at both stages of lactation $(P \leq 0.001)$. The increases in vaginal temperatures were more pronounced in lactating cows than in dry cows $\left(+1.05\right.$ vs. $+0.10^{\circ} \mathrm{C}$ in lactating and dry cows, respectively). The high increase in the vaginal temperatures of lactating cows indicates their inability to regulate their body temperature. In accordance with Silanikove (2000), this difference in body temperature of $1^{\circ} \mathrm{C}$ between lactating cows at $\mathrm{HT}$ and TN was associated with a decrease in DMI and MY. On average, the daily heart rate was also lower at HT than at TN in lactating cows (-6.91 pulses/ $\min ;$ SED $=6.10 ; P \leq 0.05$ ), which may have been a strategy to decrease the basal heat production.

Blood $\mathrm{pCO}_{2}$ was higher in $\mathrm{HT}$ than in $\mathrm{TN}$ at 0800 and $1500 \mathrm{~h}$ in lactating cows $(P \leq 0.01$; Table 3$)$ and at $1500 \mathrm{~h}$ in dry cows $(P \leq 0.05$; Table 3$)$; this partial pressure reached values above $45 \mathrm{~mm}$ of $\mathrm{Hg}$ in lactating cows at TN, especially at $1500 \mathrm{~h}$. This result was in accordance with the increased respiration rate of cows on the HT treatment. Consequently, blood $\mathrm{pH}$ was markedly higher in HT than in TN in lactating cows at 0800 and $1500 \mathrm{~h}(P \leq 0.001$; Table 3$)$, and in dry cows, the blood $\mathrm{pH}$ was higher at $0800 \mathrm{~h}(P \leq 0.05)$. Blood $\mathrm{pH}$ always exceeded 7.45 in lactating cows at HT. Ambient temperature did not affect concentration of $\mathrm{HCO}_{3}{ }^{-}$or base excess, indicating that cows did not compensate high blood $\mathrm{pH}$ by an increased excretion of $\mathrm{HCO}_{3}{ }^{-}$.

\section{Water Intake, Urine and Fecal Excretion, and Water Balance}

Free water intake was higher at HT than at TN, with values of 8.3 and $14.4 \mathrm{~kg} / \mathrm{d}$ for lactating and dry cows, 
Table 3. Effects of ambient temperature and Na supplementation on vaginal temperature, respiration and heart rates, and blood gas measurements of lactating and dry cows at 0800 and $1500 \mathrm{~h}$

\begin{tabular}{|c|c|c|c|c|c|c|c|c|c|}
\hline Item & Stage $^{1}$ & \multicolumn{4}{|c|}{ Treatment $^{2}$} & $\mathrm{SEM}^{3}$ & \multicolumn{3}{|c|}{$P$-value ${ }^{4}$} \\
\hline \multicolumn{10}{|l|}{ Daily average } \\
\hline \multirow[t]{2}{*}{ Vaginal temperature $\left({ }^{\circ} \mathrm{C}\right)$} & Lact & 38.4 & 38.3 & 39.4 & 39.4 & \multirow[t]{2}{*}{0.09} & $\leq 0.001$ & 0.62 & $\leq 0.10$ \\
\hline & Dry & 38.3 & 38.3 & 38.4 & 38.4 & & $\leq 0.05$ & 0.71 & 0.21 \\
\hline \multirow{2}{*}{ Heart rate (/min) } & Lact & 66.9 & 68.3 & 59.9 & 61.5 & \multirow[t]{2}{*}{4.31} & $\leq 0.05$ & 0.55 & 0.96 \\
\hline & Dry & 59.9 & 58.3 & 55.7 & 57.6 & & 0.35 & 0.94 & 0.50 \\
\hline \multicolumn{10}{|l|}{$0800 \mathrm{~h}$} \\
\hline \multirow[t]{2}{*}{ Blood $\mathrm{pH}$} & Lact & 7.443 & 7.447 & 7.488 & 7.500 & \multirow[t]{2}{*}{0.0149} & $\leq 0.01$ & 0.58 & 0.78 \\
\hline & Dry & 7.372 & 7.413 & 7.420 & 7.426 & & $\overline{\leq} 0.05$ & $\leq 0.1$ & 0.20 \\
\hline \multirow[t]{2}{*}{$\mathrm{pCO}_{2}^{5}(\mathrm{~mm}$ of $\mathrm{Hg})$} & Lact & 44.9 & 47.7 & 40.9 & 40.6 & \multirow[t]{2}{*}{2.01} & $\leq 0.01$ & 0.50 & 0.39 \\
\hline & Dry & 41.6 & 44.7 & 41.0 & 40.3 & & 0.20 & 0.51 & 0.32 \\
\hline \multirow[t]{2}{*}{ Blood pH } & Lact & 7.434 & 7.461 & 7.480 & 7.486 & \multirow[t]{2}{*}{0.0120} & $\leq 0.01$ & 0.16 & 0.37 \\
\hline & Dry & 7.416 & 7.420 & 7.423 & 7.441 & & 0.25 & 0.34 & 0.52 \\
\hline \multirow[t]{2}{*}{$\mathrm{pCO}_{2}(\mathrm{~mm}$ of $\mathrm{Hg})$} & Lact & 46.1 & 47.8 & 41.3 & 41.8 & \multirow{2}{*}{1.73} & $\leq 0.01$ & 0.42 & 0.64 \\
\hline & Dry & 43.1 & 43.7 & 39.9 & 39.8 & & $\leq 0.05$ & 0.84 & 0.77 \\
\hline \multirow{2}{*}{$\mathrm{HCO}_{3}^{-}(\mathrm{mmol} / \mathrm{L})$} & Lact & 30.6 & 34.3 & 30.9 & 31.5 & \multirow[t]{2}{*}{1.17} & 0.15 & $\leq 0.05$ & 0.10 \\
\hline & Dry & 27.4 & 28.0 & 25.9 & 26.9 & & 0.15 & 0.38 & 0.83 \\
\hline Base excess (mmol/L) & Lact & 6.4 & 10.0 & 7.1 & 7.8 & 1.12 & 0.38 & $\leq 0.05$ & $\leq 0.10$ \\
\hline & Dry & 3.2 & 3.8 & 2.0 & 3.1 & & 0.25 & 0.34 & 0.74 \\
\hline
\end{tabular}

respectively (Table 4 ). In lactating cows, water excreted in urine increased by $2.62 \mathrm{~kg} / \mathrm{d}(P \leq 0.01)$ at $\mathrm{HT}$ and fecal water excretions decreased by $8.6 \mathrm{~kg}$ (SED = 1.99; $P \leq 0.01$ ). The urine and fecal water excretions of dry cows was unaffected by ambient temperature. The calculated volume of evaporated water increased in both dry and lactating cows at HT (from 20 to 35 $\mathrm{kg} / \mathrm{d}$ for lactating cows and from 15 to $29 \mathrm{~kg} / \mathrm{d}$ for dry cows; $P \leq 0.01$ ), with no significant interaction between temperature and physiological stage.

For dry cows, the increase in evaporated water at HT was very similar to the increase in FWI $(+13.9$ and $+14.3 \mathrm{~kg} / \mathrm{d}$ at HT and TN, respectively). This illustrates that water evaporation became an important mechanism of dissipating body heat as ambient temperature increased above the upper limit of thermoneutrality (Silanikove, 2000). The water evaporation increases we observed were in the range of those reported in experiments performed with lactating cows under similar conditions using similar methodologies (McDowell et al., 1969; Kurihara et al., 1984). We also observed that the total amount of water lost to evaporation was higher for lactating cows than for dry cows, which is consistent with the notion that lactating cows have more heat to dissipate because of their higher metabolic rate. Water evaporation in our experiment was calculated as the difference between input and output flows of the pool of water contained in the organism. An advantage of this simple method is that it gives an individual and integrated assessment of the water evaporated at the scale of the entire animal during an entire day; however, the main risk of this method is the accumulation of measurement errors for all other flows (urine, feces, intake, and water retention) or of errors associated with calculations of metabolic water. In this experiment, special care was applied to limit water losses during measurement and sampling. Fecal samplings were adapted to the particular aim of this experiment by calculating the amount of daily fecal water excretion as the ratio between the daily amount of fecal DM excreted and the DM content of feces determined by sequential sampling at 2 -h intervals. Be- 
Table 4. Effects of ambient temperature and Na supplementation on water intake and excretions of dry and lactating cows



${ }^{1}$ Lact $=$ lactating cows; Dry $=$ dry cows.

${ }^{2} \mathrm{TN}=$ thermoneutrality; $\mathrm{HT}=$ high temperature; $\mathrm{Na}-=$ diet formulated with a low level of $\mathrm{Na}$ supplementation $\left(5.0 \mathrm{~g} / \mathrm{kg}\right.$ of $\left.\mathrm{NaHCO}_{3}{ }^{-}\right) ; \mathrm{Na}_{+}$ $=$ diet formulated with a high level of Na supplementation $\left(19.0 \mathrm{~g} / \mathrm{kg}\right.$ of $\left.\mathrm{NaHCO}_{3}{ }^{-}\right)$.

${ }^{3}$ Standard error of the mean of the effect of the stage $\times$ temperature $\times$ Na supplementation interaction.

${ }^{4}$ Temp $=$ temperature; $\mathrm{Na}=\mathrm{Na}$ supplementation; Temp $\times \mathrm{Na}=$ interaction between both effects.

${ }^{5}$ Metabolic water was estimated using the equivalent of $0.15 \mathrm{~g} / \mathrm{d}$ of water produced per kilocalorie of heat production.

${ }^{6}$ Retained water was calculated as the difference between 2 successive BW measurements divided by 7 .

${ }^{7}$ Evaporated water was calculated as the difference between water intake (free water intake, ingested with feed and metabolic water) and water excretion (milk, urine, and feces), adjusted with the volume of water exchanged in the animal (retained water).

fore the experiment was conducted, we confirmed that this sampling procedure prevents significant water loss due to evaporation from fecal samples. Urine containers were closed to avoid evaporation, and, during the experiment, we checked that cows did not waste water from their bowls. The estimations of water retention and metabolic water were based on assumptions about the linearity of water retention during the measurement period and the assessment of metabolic water produced from the INRA energy system for ruminants (INRA, 2007), as described in the Materials and Methods section; however, the values of these flows were very small.

Notably, the amounts of evaporated water measured in our experiment, at least at HT, were very similar to those predicted by the equations of latent heat loss in lactating Holstein cows established by Maia et al. (2005a,b), assuming that the skin surface of the cows was approximately $6.5 \mathrm{~m}^{2}$ and that $1 \mathrm{~L}$ of evaporated water resulted in the loss of 2,500 kJ. The equations of Maia et al. (2005a,b) were obtained from the direct measurement of body evaporation using ventilated capsules held for 5 to $10 \mathrm{~min}$ on 3 regions of the cow's body and respiratory masks. The equations of Maia et al. (2005a,b) allow prediction of both cutaneous and respi- ratory latent loss from ambient temperatures; however, several other equations have also been published, and Thompson et al. (2011) found that these equations produced highly variable predictions of cutaneous latent heat loss. For instance, for the same skin temperature of $37^{\circ} \mathrm{C}$, the predicted sweating rate from 4 predictive equations can vary 4 -fold (Thompson et al., 2011). Assuming that the skin temperature can reflect a same ratio of heat load/liveweight for different physiological stages, it is likely that the variability in the results of these predictive equations largely results from the methodologies used in the measurement of supporting data. Methodologies for measuring sweat rates can range from the direct measurement of sweating rate by sophisticated ventilated capsules or with the measurement of water charges on paper disks placed on the skin (Thompson et al., 2011) to indirect measurements over the course of a few minutes obtained by precisely and continuously weighing an animal (Ehrlemark, 1991). However, it is noteworthy that, in all of the equations reported by Thompson et al. (2011), a surface temperature of $29^{\circ} \mathrm{C}$ never produced a sweating rate of more than $10 \mathrm{~L} / \mathrm{d}$ in a $600-\mathrm{kg}$ cow, which is much lower than the predicted daily amount of water lost to evaporation 
in dairy cows obtained by calculating the difference between water intake and excretions at thermoneutrality (McDowell et al., 1969; Kurihara et al., 1984; Silanikove et al., 1997). Considering that respiratory loss may represent only a small proportion of total water loss (Maia et al., 2005a,b), it is likely that the difference between the evaporative water losses predicted by the equation based on direct measurements and the amount predicted by daily measurements of evaporation made in the water balance experiment could be explained by the fact that the amount of water lost to evaporation measured by direct measurement may be at the limit of the detection threshold when cows are subjected to ambient temperatures less than $15^{\circ} \mathrm{C}$. For instance, the cutaneous evaporation measured by Maia et al. (2005a) was measured with a capsule area of $0.00724 \mathrm{~m}^{2}$ placed on the skin of the animal for 10 min; for a dairy cow with a surface area of $6.5 \mathrm{~m}^{2}$ and a daily evaporation of $20 \mathrm{~L}$, only $0.2 \mathrm{~mL}$ of the water lost to evaporation will be captured in the capsule of $0.2 \mathrm{~mL}$ under thermoneutral conditions. The quantity of water lost to evaporation at low temperatures has been qualified as insensible sweating or perspiration (Silanikove, 2000).

\section{Effect of Temperature on the Compensation Between Water Flows and on Water Flows Expressed as a Proportion of DMI}

In dry cows, the increase in water evaporation due to HT was completely compensated for by an equivalent increase in water intake (Table 4), likely because DMI of these cows was not affected by ambient temperature. In lactating cows, the increase in water evaporation at HT $(+15.2 \mathrm{~kg} / \mathrm{d} ; \mathrm{SED}=3.65 ; P \leq 0.01)$ was equally compensated for by an increase in FWI $(+8.3 \mathrm{~kg} / \mathrm{d}$; $\mathrm{SED}=2.57 ; P \leq 0.01)$ and by a decrease in the daily amount of water excreted in feces $(-8.6 \mathrm{~kg} / \mathrm{d} ;$ SED = $2.29 ; P \leq 0.01)$. However, when water flows were reported as a proportion of DMI (Table 5), the increase in water evaporation at high ambient temperatures $(+0.92$ $\mathrm{kg} / \mathrm{kg}$ of DMI per day; SED $=0.182$ ) was completely compensated for by the increase in FWI $(+0.92 \mathrm{~kg} /$ $\mathrm{kg}$ of DMI per day; SED =0.170) in both dry and lactating cows. For lactating cows, all water flows reported as a proportion of DMI were highly affected by ambient temperature $(P \leq 0.01)$, with the exception of milk water and water ingested with feed. However, the amplitude of the variation in fecal and urinary flows $(-0.175$ and $+0.245 \mathrm{~kg} / \mathrm{kg}$ of DMI, respectively) was lower than the amplitude of the variation in FWI and evaporated water $(+0.92 \mathrm{~kg} / \mathrm{kg}$ of DMI).

These observations were consistent with those of McDowell et al. (1969) and Richards (1985), who measured water balances of dairy cows exposed to various ambient temperatures. Kurihara et al. (1984) also observed a clear association between water evaporation and FWI reported as a proportion of DMI in lactating cows when ambient temperatures increased; however, those authors also observed a huge increase in the volume of water excreted in urine in dry cows with increasing ambient temperature $\left(+5.4 \mathrm{~L} / \mathrm{d}\right.$ between 18 and $32^{\circ} \mathrm{C}$, comparable to the volume of evaporated water of +7.1 $\mathrm{L} / \mathrm{d}$ ), leading to a huge increase in FWI. A possible explanation for this discrepancy in results is that cows in our experiment had more than $10 \mathrm{~d}$ to acclimate to the high ambient temperatures, whereas those from the experiment of Kurihara et al. (1984) had less than 5 d. The adaptation of cows to heat stress has been shown to increase the extracellular water pool in these animals (Silanikove, 2000), which likely increases the body heat load capacity and buffers the rise in core body temperature. Richards (1985) suggested that this increase may mainly occur during the first days of heat stress, as illustrated by the important variations in liveweight he observed during the first week of his experiment. By the second week, he observed that the liveweight of cows returned to preexperiment values, likely because other adaptive processes such as the progressive increase in the flow of evaporated water were largely initiated (McDowell et al., 1969). The increase in urinary flow observed by Kurihara et al. (1984) in dry cows after $5 \mathrm{~d}$ of heat stress could be due to the decrease in the extracellular water compartment of these cows after the implementation of the first adaptive processes. A similar phenomenon was not observed in lactating cows possibly because their first adaptive mechanism was to decrease milk yield or because the electrolyte status was different in dry and lactating cows, given that the diet composition was not adapted for each physiological stage.

The fact that the increase in water evaporation at high ambient temperatures was completely compensated for by the increase in FWI when water flows were reported as a proportion of DMI provides an interesting new way of predicting the effects of high temperatures on water needs of dairy cows independently of the effect of heat on other variables such as dietary DM, MY, or DMI that may affect FWI at thermoneutral conditions (Khelil-Arfa et al., 2012). A significant amount of data produced equations to predict the effect of the diet or the cow's level of production on her water requirements (Murphy et al., 1983; Holter and Urban, 1992; Khelil-Arfa et al., 2012). However, a small proportion of these data were collected at high ambient temperatures. Moreover, most equations were produced by multiple regressions in which the effect of the ambient temperature, when included, could have 
Table 5. Effects of ambient temperature and Na supplementation on water intake and excretions expressed as a proportion of DMI of dry and lactating cows

\begin{tabular}{|c|c|c|c|c|c|c|c|c|c|}
\hline \multirow[b]{2}{*}{$\begin{array}{l}\text { Item } \\
(\mathrm{kg} / \mathrm{kg} \text { of DMI per day) }\end{array}$} & \multirow[b]{2}{*}{ Stage $^{1}$} & \multicolumn{4}{|c|}{ Treatment $^{2}$} & \multirow[b]{2}{*}{$\mathrm{SEM}^{3}$} & \multicolumn{3}{|c|}{$P$-value ${ }^{4}$} \\
\hline & & $\mathrm{Na}-$ & $\mathrm{Na}+$ & $\mathrm{Na}-$ & $\mathrm{Na}+$ & & Temp & $\mathrm{Na}$ & Temp $\times \mathrm{Na}$ \\
\hline \multicolumn{10}{|l|}{ Measured input } \\
\hline \multirow[t]{2}{*}{ Free water intake } & Lact & 3.56 & 3.75 & 4.46 & 4.68 & \multirow[t]{2}{*}{0.120} & $\leq 0.01$ & $\leq 0.10$ & 0.91 \\
\hline & Dry & 1.83 & 2.10 & 2.95 & 3.06 & & $\overline{\leq} 0.01$ & $\overline{\leq} 0.10$ & 0.42 \\
\hline \multicolumn{10}{|l|}{ Measured output } \\
\hline \multirow[t]{2}{*}{ Urine output } & Lact & 0.73 & 0.94 & 0.88 & 1.28 & \multirow{2}{*}{0.066} & $\leq 0.01$ & $\leq 0.01$ & $\leq 0.10$ \\
\hline & Dry & 0.85 & 1.10 & 0.82 & 1.16 & & 0.72 & $\leq 0.01$ & 0.37 \\
\hline \multirow[t]{2}{*}{ Fecal water } & Lact & 2.29 & 2.24 & 2.16 & 2.02 & \multirow[t]{2}{*}{0.116} & $\leq 0.01$ & 0.11 & 0.46 \\
\hline & Dry & 1.70 & 1.68 & 1.76 & 1.65 & & 0.81 & 0.27 & 0.44 \\
\hline Milk water & Lact & 1.3 & 1.2 & 1.3 & 1.3 & 0.06 & 0.18 & 0.43 & 0.38 \\
\hline \multicolumn{10}{|l|}{ Balance } \\
\hline Evaporated water ${ }^{7}$ & Dry & 0.95 & 0.96 & 2.05 & 1.86 & 0.129 & $\leq 0.01$ & 0.28 & 0.26 \\
\hline
\end{tabular}

${ }^{1}$ Lact $=$ lactating cows; Dry $=$ dry cows.

${ }^{2} \mathrm{TN}=$ thermoneutrality; $\mathrm{HT}=$ high temperature; $\mathrm{Na}-=$ diet formulated with a low level of $\mathrm{Na}$ supplementation $\left(5.0 \mathrm{~g} / \mathrm{kg}\right.$ of $\left.\mathrm{NaHCO}_{3}{ }^{-}\right) ; \mathrm{Na}_{+}$ $=$ diet formulated with a high level of $\mathrm{Na}$ supplementation $\left(19.0 \mathrm{~g} / \mathrm{kg}\right.$ of $\left.\mathrm{NaHCO}_{3}{ }^{-}\right)$.

${ }^{3}$ SEM: standard error of means of the effect of the interaction stage $\times$ temperature $\times$ Na supplementation.

${ }^{4}$ Temp $=$ temperature; $\mathrm{Na}=\mathrm{Na}$ supplementation; Temp $\times \mathrm{Na}=$ interaction between both effects.

${ }^{5}$ Metabolic water was estimated using the equivalent of $0.15 \mathrm{~g} / \mathrm{d}$ of water produced per kilocalorie of heat production.

${ }^{6}$ Retained water was calculated as the difference between 2 successive BW measurements divided by 7 .

${ }^{7}$ Evaporated water was calculated as the difference between water intake (free water intake, ingested with feed and metabolic water) and water excretion (milk, urine, and feces), adjusted with the volume of water exchanged in the animal (retained water).

been confounded with the effect of season on feeding and lactation management. A more mechanistic way of including temperature in predictive equations would allow better adaptation of predictive equations to various geographic localizations. One way of adapting the equations developed in thermoneutral conditions to high temperature contexts would be to add the amount of water lost to evaporation at the considered temperature to the water requirement at thermoneutrality. The amount of water lost to evaporation could be obtained from predictive equations of the effects of ambient temperature on latent heat loss in cows, assuming that the vaporization of $1 \mathrm{~L}$ of water at $39^{\circ} \mathrm{C}$ results in the loss of 2,500 kJ of latent heat. The equations of Maia et al. (2005a,b) fit our data well. The equation of the Commission Internationale du Genie Rural (CIGR, 2002) largely underpredicted the water lost to evaporation in our experiment, likely because this equation was not developed specifically for the high heat loss of lactating cows. Several other mechanistic models of heat loss in cattle have been published that also describe the effect of meteorological descriptors other than ambient temperature, such as wind speed or solar radiation that modify latent heat loss (Turnpenny et al., 2000).

\section{Lack of Significant Effect of Na Supplementation on the Adaptability of Cows to Heat}

The supplementation of the diet with $\mathrm{Na}$ or K bicarbonates has been recommended as a way of improving acid-base regulation and thus enhancing heat adaptation in cows (West, 2003). As observed in the present experiment, high ambient temperatures can induce increased respiration rates (for thermoregulation) that can lead to decreased blood $\mathrm{pCO}_{2}$ and increased blood $\mathrm{pH}$. Schneider et al. (1988) observed that the variations in blood $\mathrm{pCO}_{2}$ and $\mathrm{pH}$ could be high enough to produce respiratory alkalosis, which would, in turn, produce compensatory increase in the renal excretion of bicarbonates to restore the blood $\mathrm{pCO}_{2} / \mathrm{HCO}_{3}{ }^{-}$ratio and $\mathrm{pH}$. This compensation can even lead to nocturnal metabolic acidosis (Schneider et al., 1988). We expected Na bicarbonate supplementation to enhance the ability of cows to adapt to the heat by avoiding a nocturnal decrease in plasmatic pH (Schneider et al., 1988), by inducing compensatory excretion of $\mathrm{Na}$ along with bicarbonate (West, 2003) and by sparing K for the loss of electrolytes associated with cutaneous water evaporation (El-Nouty et al., 1980; West, 2003). 
In the present experiment, compared with the $\mathrm{Na}-$ diet, the $\mathrm{Na}+$ diet led to slightly improved DMI of lactating cows $(+0.5 \mathrm{~kg} / \mathrm{d} ; P \leq 0.05$; Table 2$)$; however, this slight increase in DMI with the $\mathrm{Na}^{+}$diet was similar at TN and HT (interaction between Na supplementation and ambient temperature: $P>0.15$ ). Sodium supplementation did not affect milk production and increased milk DM and fat content $(P \leq 0.05)$. Milk production and composition were unaffected by the interaction between $\mathrm{Na}$ supplementation and ambient temperature $(P>0.10)$. For dry cows, DMI was similar to the fed amounts for both $\mathrm{Na}-$ and $\mathrm{Na}+$.

Sodium supplementation did not improve indicators of heat adaptation of dairy cows, such as vaginal temperature or blood $\mathrm{pH}$ (Table 3). In both lactating and dry cows, daily vaginal temperatures were unaffected by Na supplementation $(P>0.15)$. Sodium supplementation did not decrease vaginal temperature at HT even though the interaction between ambient temperature and $\mathrm{Na}$ supplementation tended to be significant in lactating cows $(P \leq 0.10)$. Blood $\mathrm{pH}$ only tended to be higher on the $\mathrm{Na}+$ diet in dry cows $(P \leq 0.10)$ and was always unaffected by the interaction between ambient temperature and $\mathrm{Na}$ supplementation in both dry and lactating cows $(P>0.10)$. At $0800 \mathrm{~h}$ in dry cows and at $1500 \mathrm{~h}$ in lactating cows, the concentration of $\mathrm{HCO}_{3}^{-}$and the base excess were higher in animals fed the $\mathrm{Na}^{+}$diet than in animals fed the $\mathrm{Na}-\operatorname{diet}(P \leq$ $0.05)$. This difference was more pronounced at TN than at HT (interaction temperature $\times \mathrm{Na}$ supplementation: $P \leq 0.05$ for dry cows and $P \leq 0.10$ for lactating cows).

The increase in DMI in lactating cows given the $\mathrm{Na}^{+}$diet in the present experiment was lower than the increases in DMI reported in lactating cows supplemented with $\mathrm{Na}$ at high temperatures by other authors (Escobosa et al., 1984; Schneider et al., 1986; West, 2003). The main reason for this observation must be that the low chloride content of the diet offered to cows in this experiment produced high diet electrolyte balances (EB) in cows fed the $\mathrm{Na}-$ and $\mathrm{Na}+$ diets. The EB of diets in the current experiment was largely over $200 \mathrm{mEq} / \mathrm{kg}$ of $\mathrm{DM}$, a threshold value at which increases in EB result in increased DMI, albeit with very low marginal yields (Meschy, 2010). In all previous experiments (Escobosa et al., 1984; Schneider et al., 1986; West, 2003), control treatments consisted of diets with an EB lower than $200 \mathrm{mEq} / \mathrm{kg}$ of DMI. Because of the low chloride content of the corn silage used in our experiment, $\mathrm{Cl}$ contents of the diets did not meet $\mathrm{Cl}$ requirements of cows, as illustrated below by their negative chloride balances and their low concentrations of urinary chloride (Meschy, 2010). In lactating cows, low chloride contents of the diet were likely responsible for the high concentrations of blood bicarbonates, (ex- ceeding $28 \mathrm{mmol} / \mathrm{L}$ ) and high base excess (exceeding 8 $\mathrm{mEq} / \mathrm{L}$ ), which are symptomatic of a metabolic alkalosis (Offenstadt and Bernardin, 2009).

\section{A Few Interactions Between Na Supplementation and Ambient Temperature on Water Flows}

Sodium supplementation enhanced the FWI of lactating cows $(+5.5 \mathrm{~kg} / \mathrm{d} ; \mathrm{SED}=2.57 ; P \leq 0.05$; Table 4) but did not affect FWI of dry cows $(P>0.10)$. Sodium supplementation also increased the amount of water excreted in urine in both lactating $(+6.5 \mathrm{~kg} / \mathrm{d}$; $\mathrm{SEM}=1.78 ; P \leq 0.01 ;$ Table 4$)$ and dry cows $(+4.1$ $\mathrm{kg} / \mathrm{d} ; \mathrm{SEM}=1.78 ; P \leq 0.01)$. In lactating cows, the increase in the amount of water excreted in urine with the $\mathrm{Na}^{+}$diet was higher at HT compared with TN $(+4.7$ and $+8.2 \mathrm{~kg} / \mathrm{d}$ at TN and HT, respectively; interaction of ambient temperature $\times$ Na supplementation: $P \leq$ $0.05)$. Neither Na supplementation nor the interaction between Na supplementation and ambient temperature affected the other water flows at either stage of lactation. When water flows were reported as a proportion of DMI (Table 5), the $\mathrm{Na}^{+}$diet also tended to enhance the FWI of lactating $(+0.21 \mathrm{~kg} / \mathrm{kg}$ of DMI; SED = $0.170 ; P \leq 0.10)$ and dry cows $(+0.19 \mathrm{~kg} / \mathrm{kg}$ of DMI; $\mathrm{SED}=0.170 ; P \leq 0.10)$ and enhanced the urinary water excretion $(+0.31 \mathrm{~kg} / \mathrm{kg}$ of DMI for lactating cows and $+0.30 \mathrm{~kg} / \mathrm{kg}$ of DMI for dry cows; SED =0.093; $P \leq 0.01)$. The effect of the interaction between $\mathrm{Na}$ supplementation and ambient temperature tended to be significant in lactating cows $(P \leq 0.10)$.

The increase in water intake was consistent with the increase predicted by the equations of Murphy et al. (1983). This increase was most likely related to the stimulation of the thirst center by the increased plasma osmolarity produced by increased $\mathrm{Na}$ ingestion (Offenstadt and Bernardin, 2009). The increase in urinary excretion was also consistent with the increase predicted by the equations of Nennich et al. (2006) and was likely related to the inhibition of the reninangiotensin-aldosterone system and the reduction in the renal reabsorption of $\mathrm{Na}$ and water in response to the increased extracellular fluid volume produced by the increased amount of ingested $\mathrm{Na}$ (Offenstadt and Bernardin, 2009). The increase in urinary excretion in highly supplemented cows is associated with the fact that urine excretion is the main homeostatic way of regulating $\mathrm{Na}$ and K (Offenstadt and Bernardin, 2009). The current study illustrates an additive effect of $\mathrm{Na}$ and heat on FWI in both lactating and dry cows.

\section{Electrolyte Balances}

In the present experiment, $\mathrm{Na}$ balances were not different from zero $(P>0.10)$ except for in lactating cows 
Table 6. Effects of ambient temperature and Na supplementation on the mineral balance of dry and lactating cows

\begin{tabular}{|c|c|c|c|c|c|c|c|c|c|}
\hline \multirow[b]{2}{*}{ Item } & \multirow[b]{2}{*}{ Stage $^{1}$} & \multicolumn{4}{|c|}{ Treatment $^{2}$} & \multirow[b]{2}{*}{$\mathrm{SEM}^{3}$} & \multicolumn{3}{|c|}{$P$-value ${ }^{4}$} \\
\hline & & $\mathrm{Na}-$ & $\mathrm{Na}+$ & $\mathrm{Na}-$ & $\mathrm{Na}+$ & & Temp & $\mathrm{Na}$ & Temp $\times \mathrm{Na}$ \\
\hline \multicolumn{10}{|l|}{$\mathrm{Na}(\mathrm{g} / \mathrm{d})$} \\
\hline \multirow[t]{2}{*}{ Free water intake } & Lact & 2.1 & 2.3 & 2.4 & 2.6 & \multirow[t]{2}{*}{0.07} & $\leq 0.01$ & $\leq 0.05$ & 0.95 \\
\hline & Dry & 0.7 & 0.8 & 1.2 & 1.2 & & $\leq 0.01$ & 0.25 & 0.68 \\
\hline Urinary & Dry & 13.7 & 46.0 & 14.1 & 52.1 & 4.27 & 0.42 & $\leq 0.0001$ & 0.48 \\
\hline \multirow[t]{2}{*}{ Fecal } & Lact & 13.2 & 30.7 & 10.9 & 16.0 & \multirow[t]{2}{*}{2.73} & $\leq 0.001$ & $\leq 0.0001$ & $\leq 0.01$ \\
\hline & Dry & 11.7 & 15.7 & 9.1 & 14.0 & & 0.23 & $\leq 0.05$ & 0.77 \\
\hline Milk & Lact & 13.2 & 10.8 & 10.7 & 10.7 & 1.07 & 0.23 & 0.26 & 0.27 \\
\hline \multirow{2}{*}{ Balance $^{5}$} & Lact & 3.8 & $7.9^{*}$ & 1.3 & -4.5 & \multirow[t]{2}{*}{3.48} & $\leq 0.05$ & 0.80 & 0.13 \\
\hline & Dry & 3.7 & 7.3 & 6.4 & 3.3 & & 0.83 & 0.95 & 0.29 \\
\hline \multirow[t]{2}{*}{ Urinary } & Lact & 158.2 & 150.4 & 153.5 & 170.7 & \multirow[t]{2}{*}{8.62} & 0.31 & 0.54 & 0.12 \\
\hline & Dry & 134.4 & 134.1 & 130.7 & 140.1 & & 0.88 & 0.55 & 0.52 \\
\hline Fecal & Lact & 39.3 & 35.9 & 29.2 & 20.0 & 3.12 & $\leq 0.01$ & $\leq 0.05$ & 0.31 \\
\hline & Dry & 20.6 & 14.2 & 18.1 & 12.2 & & 0.43 & $\leq 0.05$ & 0.92 \\
\hline Milk & Lact & 54.0 & 50.4 & 46.5 & 48.0 & 1.75 & $\leq 0.05$ & 0.52 & 0.16 \\
\hline Balance $^{5}$ & Lact & 3.9 & $35.1 * *$ & -4.7 & 5.4 & 3.21 & $\leq 0.05$ & $\leq 0.05$ & 0.22 \\
\hline & Dry & 13.9 & $28.9^{* *}$ & $20.2^{*}$ & $25.0^{*}$ & & 0.88 & 0.24 & 0.54 \\
\hline $\mathrm{Cl}(\mathrm{g} / \mathrm{d})$ & & & & & & & & & \\
\hline Free water intake & Lact & 4.9 & 5.3 & 5.5 & 5.9 & 0.17 & $\leq 0.01$ & $\leq 0.05$ & 0.94 \\
\hline & Dry & 1.7 & 1.9 & 2.7 & 2.8 & & $\leq 0.01$ & 0.27 & 0.67 \\
\hline Feed & Lact & 26.7 & 27.4 & 23.8 & 24.4 & 0.9 & $\leq 0.001$ & 0.36 & 0.93 \\
\hline & Dry & 17.7 & 17.8 & 17.7 & 17.8 & & 1.00 & 0.84 & 1.00 \\
\hline Urinary & Lact & 6.9 & 6.7 & 6.1 & 7.6 & 1.20 & 0.99 & 0.58 & 0.49 \\
\hline & Dry & 19.3 & 22.2 & 18.5 & 22.7 & & 0.90 & $\leq 0.05$ & 0.58 \\
\hline
\end{tabular}

${ }^{1}$ Lact $=$ lactating cows; Dry $=$ dry cows.

${ }^{2} \mathrm{TN}=$ thermoneutrality; $\mathrm{HT}=$ high temperature; $\mathrm{Na}-=$ diet formulated with a low level of $\mathrm{Na}$ supplementation $\left(5.0 \mathrm{~g} / \mathrm{kg}\right.$ of $\left.\mathrm{NaHCO}_{3}{ }^{-}\right) ; \mathrm{Na}_{+}$ $=$ diet formulated with a high level of Na supplementation $\left(19.0 \mathrm{~g} / \mathrm{kg}\right.$ of $\left.\mathrm{NaHCO}_{3}{ }^{-}\right)$.

${ }^{3}$ Standard error of the mean of the effect of the stage $\times$ temperature $\times$ Na supplementation interaction.

${ }^{4}$ Temp $=$ temperature; $\mathrm{Na}=\mathrm{Na}$ supplementation; Temp $\times \mathrm{Na}=$ interaction between both effects.

${ }^{5}$ Balance $=($ free water intake + ingested with feed $)-($ urine + feces + milk $)$.

${ }^{*} P \leq 0.05 ;{ }^{* *} P \leq 0.01$; ${ }^{* *} P \leq 0.001$ (for the test of null balance).

fed the Na+ diet at TN $(P \leq 0.05$; Table 6$)$. Potassium balances were positive for lactating cows fed the $\mathrm{Na}+$ diet at TN $(P \leq 0.01)$, for dry cows fed the Na+ diet at TN $(P \leq 0.01)$, and for dry cows at HT regardless of the level of $\mathrm{Na}$ supplementation $(P \leq 0.05)$. Potassium balances were not different from 0 for the other modalities. Chloride balances were always negative in lactating and dry cows $(P>0.01)$, showing that the amount of $\mathrm{Cl}$ provided by the diet did not cover cow requirements.

Even though HT increased the amount of water lost to evaporation in both lactating and dry cows, we did not observe increases in the $\mathrm{K}$ and $\mathrm{Na}$ balances at $\mathrm{HT}$ that would account for the electrolytes lost in the sweat or retained in the organism. This observation is likely related to the fact that bovine sweat has lower concentrations of electrolytes than plasma or urine, as long as the temperature did not exceed extreme values of 40 to $45^{\circ} \mathrm{C}$ (Jenkinson and Mabon, 1973). In lactating cows, HT even decreased the $\mathrm{Na}$ and $\mathrm{K}$ balances $(P \leq$ $0.05)$ and increased the $\mathrm{Cl}$ balance $(P \leq 0.05)$ in the current study. This is most likely because the alkalosis experienced by the cows could induced a systematic regulation favoring $\mathrm{Na}$ and $\mathrm{K}$ excretion and $\mathrm{Cl}$ reten- 
tion to decrease the plasmatic strong ion difference that can be estimated as the difference between the $\mathrm{Na}, \mathrm{K}$, and $\mathrm{Cl}$ plasma concentrations. The plasma strong ion difference is positively correlated with the plasma $\mathrm{pH}$ according to the strong ions theory (Constable, 1999).

Sodium supplementation had no effect on $\mathrm{Na}$ and $\mathrm{Cl}$ balances $(P>0.15)$, confirming the fact that the amount of $\mathrm{Na}$ in the organism is tightly regulated and that $\mathrm{Cl}$ is very dependent on $\mathrm{Na}$ regulation; indeed, $\mathrm{Cl}$ and $\mathrm{Na}$ are the major contributors to the anion-cation balance of the extracellular fluid. Sodium supplementation increased $\mathrm{K}$ retention in lactating cows $(P \leq$ $0.05)$, most likely because alkalosis favors intracellular $\mathrm{K}$ retention (Offenstadt and Bernardin, 2009).

\section{CONCLUSIONS}

This study demonstrated that, when body water evaporation and free water intake were expressed as a proportion of DMI, the increase in evaporation associated with increasing ambient temperatures was mainly compensated for by an increase in FWI in both dry and lactating cows fed diets with different $\mathrm{Na}$ contents. Although the urinary flow increased with ambient temperature in lactating cows, the variation in urinary output was lower than the variation in other water flows. These results provide information to better predict the effect of ambient temperature on water requirements of dairy cows independently of the effect of diets or animals with the use of models of latent heat loss.

\section{ACKNOWLEDGMENTS}

The authors are grateful to the staff of the experimental farm of Méjusseaume (INRA, UMR 1348 PEGASE, Rennes, France), in particular to P. Lamberton and all of the members of the physiology team for carrying out this experiment, and to the staff of the laboratory of UMR 1348 (INRA Agrocampus Ouest, Saint Gilles, France), in particular to T. Le Mouel, N. Huchet, C. Mustière, P. Poton, and Y. Jaguelin for their help with the laboratory analyses.

\section{REFERENCES}

AFNOR (Association Française de Normalisation). 1985. Lait, crème et lait concentré non sucré. Détermination de la matière sèche. NF V 04-367. AFNOR Éditions, La Plaine Saint-Denis, France.

AFNOR (Association Française de Normalisation). 1997. Aliments des animaux-Dosage de l'azote - Méthode par combustion (Dumas). NF V 18-120. AFNOR Éditions, La Plaine Saint-Denis, France.

AFNOR (Association Française de Normalisation). 2002. Aliments des animaux-Détermination des teneurs en calcium, cuivre, fer, magnésium, manganèse, potassium, sodium et zinc-Méthode par spectrométrie d'absorption atomique. NF EN ISO 6869. AFNOR Editions, La Plaine Saint-Denis, France.
AFNOR (Association Française de Normalisation). 2006. Aliments des animaux-Détermination du contenu en fibre par traitement à l'amylase et au détergent neutre (aNDF). NF EN ISO 16472. AFNOR Éditions, La Plaine Saint-Denis, France.

AFNOR (Association Française de Normalisation). 2008. Aliments des animaux - Détermination des teneurs en fibres au détergent acide (ADF) et en lignine sulfurique (ADL). NF EN ISO 13906. AFNOR Éditions, La Plaine Saint-Denis, France.

AFNOR (Association Française de Normalisation). 2011. Aliments des animaux-Détermination de la teneur en chlorures solubles dans l'eau. NF ISO 6495. AFNOR Éditions, La Plaine Saint-Denis, France.

Armstrong, D. V. 1994. Heat stress interaction with shade and cooling. J. Dairy Sci. 77:2044-2050.

Berman, A. 2005. Estimates of heat stress relief needs for Holstein dairy cows. J. Anim. Sci. 83:1377-1384.

Berman, A., Y. Folman, M. Kaim, M. Mamen, Z. Herz, D. Wolfenson, A. Arieli, and Y. Graber. 1985. Upper critical temperatures and forced ventilation effects for high-yielding dairy cows in a subtropical climate. J. Dairy Sci. 68:1488-1495.

Bernabucci, U., N. Lacetera, L. H. Baumgard, R. P. Rhoads, B. Ronchi, and A. Nardone. 2010. Metabolic and hormonal acclimation to heat stress in domesticated ruminants. Animal 4:1167-1183.

CIGR (Commission Internationale du Genie Rural). 2002. 4th Report of Working Group on Climatization of Animal Houses: Heat and Moisture Production at Animal and House Levels. Research Centre Bygholm, Danish Institute of Agricultural Sciences, Horsens, Denmark.

Constable, P. D. 1999. Clinical assessment of acid-base status. Strong ion difference theory. Vet. Clin. North Am. Food Anim. Pract. 15:447-471.

Ehrlemark, A. 1991. Heat and moisture dissipation from cattle: Measurements and simulation model. Rapport 77. Department of Farm Buildings, Division of Agricultural Sciences, Swedish University of Agricultural Sciences, Uppsala, Sweden.

El-Nouty, F. D., I. M. Elbanna, T. P. Davis, and H. D. Johnson. 1980 Aldosterone and $\mathrm{ADH}$ response to heat and dehydration in cattle. J. Appl. Physiol. 48:249-255.

Escobosa, A., C. E. Coppock, L. D. Rowe Jr., W. L. Jenkins, and C. E. Gates. 1984. Effects of dietary sodium bicarbonate and calcium chloride on physiological responses of lactating dairy cows in hot weather. J. Dairy Sci. 67:574-584.

Holter, J. B., and W. E. Urban Jr. 1992. Water partitioning and intake prediction in dry and lactating Holstein cows. J. Dairy Sci. $75: 1472-1479$.

INRA (Institut national de la recherche agronomique). 2007. Alimentation des bovins, ovins et caprins: Besoins des animaux: Tables INRA 2007. Éditions QUAE, Versailles, France.

Jenkinson, D. M., and R. M. Mabon. 1973. The effect of temperature and humidity on skin surface $\mathrm{pH}$ and the ionic composition of skin secretions in Ayrshire cattle. Br. Vet. J. 129:282-295.

Khelil-Arfa, H., A. Boudon, G. Maxin, and P. Faverdin. 2012. Prediction of water intake and excretion flows in Holstein dairy cows under thermoneutral conditions. Animal 6:1662-1676.

Kurihara, M., M. Shibata, and A. Mukai. 1984. The effect of environmental temperature on water economy of dry and lactating Holstein cows given high concentrate ration. Jpn. J. Livest. Manage. 20:61-67.

Mader, T. L., M. S. Davis, and T. Brown-Brandl. 2006. Environmental factors influencing heat stress in feedlot cattle. J. Anim. Sci. 84:712-719.

Maia, A. S., R. G. daSilva, and C. M. Battiston Loureiro. 2005a. Sensible and latent heat loss from the body surface of Holstein cows in a tropical environment. Int. J. Biometeorol. 50:17-22.

Maia, A. S., R. Gomes DaSilva, and C. M. Battiston Loureiro. 2005b. Respiratory heat loss of Holstein cows in a tropical environment. Int. J. Biometeorol. 49:332-336.

McDowell, R. E., E. G. Moody, P. J. Van Soest, R. P. Lehmann, and G. L. Ford. 1969. Effect of heat stress on energy and water utilization of lactating cows. J. Dairy Sci. 52:188-194. 
Mekonnen, M. M., and A. Y. Hoekstra. 2012. A global assessment of the water footprint of farm animal products. Ecosystems (N. Y.) 15:401-415.

Meschy, F. 2010. Nutrition Minérale des Ruminants. Éditions Quae, Versailles, France.

Meyer, U., M. Everinghoff, D. Gädeken, and G. Flachowsky. 2004. Investigations on the water intake of lactating dairy cows. Livest. Prod. Sci. 90:117-121.

Murphy, M. R., C. L. Davis, and G. C. McCoy. 1983. Factors affecting water consumption by Holstein cows in early lactation. J. Dairy Sci. $66: 35-38$.

Nennich, T. D., J. H. Harrison, L. M. VanWieringen, N. R. St-Pierre, R. L. Kincaid, M. A. Wattiaux, D. L. Davidson, and E. Block. 2006. Prediction and evaluation of urine and urinary nitrogen and mineral excretion from dairy cattle. J. Dairy Sci. 89:353-364.

NRC. 2001. Nutrient Requirements of Dairy Cattle. National Academic Press, Washington, DC.

Offenstadt, G., and S. Bernardin. 2009. Equilibres acido-basique et hydro-électrolytique. Pages 124-150 in Réanimation Médicale. Vol. 1. 2nd ed. G. Offenstadt, J.-M. Boles, P.-E. Bollaert, A. Jaeger, F. Saulnier, M. Wolff, and F. Zéni, ed. Elsevier Masson Paris, France.

Richards, J. I. 1985. Effect of high daytime temperatures on the intake and utilisation of water in lactating Friesian cows. Trop. Anim. Health Prod. 17:209-217.

Schneider, P. L., D. K. Beede, and C. J. Wilcox. 1986. Responses of lactating cows to dietary sodium source and quantity and potassium quantity during heat stress. J. Dairy Sci. 69:99-110.
Schneider, P. L., D. K. Beede, and C. J. Wilcox. 1988. Nycterohemeral patterns of acid-base status, mineral concentrations and digestive function of lactating cows in natural or chamber heat stress environments. J. Anim. Sci. 66:112-125.

Seif, S. M., H. D. Johnson, and L. Hahn. 1973. Environmental heat and partial water restriction effects on body fluid spaces, water loss, body temperature, and metabolism of Holstein cows. J. Dairy Sci. 56:581-586.

Silanikove, N. 2000. Effects of heat stress on the welfare of extensively managed domestic ruminants. Livest. Prod. Sci. 67:1-18.

Silanikove, N., E. Maltz, A. Halevi, and D. Shinder. 1997. Metabolism of water, sodium, potassium, and chlorine by high yielding dairy cows at the onset of lactation. J. Dairy Sci. 80:949-956.

Steiger Burgos, M., M. Senn, F. Sutter, M. Kreuzer, and W. Langhans. 2001. Effect of water restriction on feeding and metabolism in dairy cows. Am. J. Physiol. Regul. Integr. Comp. Physiol. 280:R418-R427.

Thompson, V. A., J. G. Fadel, and R. D. Sainz. 2011. Meta-analysis to predict sweating and respiration rates for Bos indicus, Bos taurus and their crossbreds. J. Anim. Sci. 89:3973-3982.

Turnpenny, J. R., A. J. McArthur, J. A. Clark, and C. M. Wathes. 2000. Thermal balance of livestock: 1. A parsimonious model. Agric. For. Meteorol. 101:15-27.

West, J. W. 2003. Effects of heat-stress on production in dairy cattle J. Dairy Sci. 86:2131-2144 